\title{
Article \\ Comparison of Sodium Nitrite and 'Natural' Nitrite on the Inhibition of Spore Germination and Outgrowth of Clostridium sporogenes in Low- and High-Fat Frankfurters
}

\author{
Arjun Bhusal ${ }^{1,2}$, Jacob Nelson ${ }^{1,2}$, Dennis Pletcher ${ }^{1,2}$ and Peter M. Muriana ${ }^{1,2, *(D)}$ \\ 1 Robert M. Kerr Food \& Agricultural Products Center, Oklahoma State University, Stillwater, OK 74078, USA; \\ arjun.bhusal@okstate.edu (A.B.); jacob.nelson@okstate.edu (J.N.); dennis.pletcher@okstate.edu (D.P.) \\ 2 Department of Animal and Food Sciences, Oklahoma State University, Stillwater, OK 74078, USA \\ * Correspondence: peter.muriana@okstate.edu; Tel.: +1-405-744-5563
}

check for

updates

Citation: Bhusal, A.; Nelson, J.; Pletcher, D.; Muriana, P.M.

Comparison of Sodium Nitrite and

'Natural' Nitrite on the Inhibition of Spore Germination and Outgrowth of Clostridium sporogenes in Low- and High-Fat Frankfurters. Appl. Microbiol. 2021, 1, 104-122. https:// doi.org/10.3390/applmicrobiol1010009

Academic Editor: Filipa Silva

Received: 19 March 2021

Accepted: 26 May 2021

Published: 27 May 2021

Publisher's Note: MDPI stays neutral with regard to jurisdictional claims in published maps and institutional affiliations.

Copyright: (C) 2021 by the authors. Licensee MDPI, Basel, Switzerland. This article is an open access article distributed under the terms and conditions of the Creative Commons Attribution (CC BY) license (https:// creativecommons.org/licenses/by/ $4.0 /)$.

\begin{abstract}
In the US, sodium and potassium nitrite are regulated food preservatives that prevent the germination of Clostridium spores in cured and processed meats. In recent years, the use of vegetable-derived nitrite (i.e., vegetable nitrate fermented to nitrite) has been designated as 'natural nitrite' to accommodate natural meats that cannot use artificial ingredients, and such meat products can be labelled as having 'no added preservatives'. This new status and labelling allowance for microbially-modified nitrite provides for a 'clean label' application of nitrite against the stigma of chemical ingredients and has found increased use within the processed meat industry. The objectives of this study were to examine Clostridium sporogenes as a pathogen-surrogate challenge organism and the use of vegetable (celery) nitrite to prevent spore germination in cooked meat products. A three-strain spore crop of C. sporogenes ATCC 3584, ATCC 19404 and ATCC BAA-2695 was applied during ingredient formulation of low and high-fat hotdogs that were divided into three sub-batches (control without nitrite, hotdogs with sodium nitrite, hotdogs with celery nitrite). In both low and high-fat processes, sodium nitrite was compared to hotdogs made with comparable levels of celery nitrite (156 ppm). All treatments were performed with duplicate trial replication and triplicate sample testing within each trial. Comparisons were analyzed by repeated measures analysis of variance to determine significant difference $(p<0.05)$ of time course treatments. In shelf-life assays, growth was inhibited at both $5{ }^{\circ} \mathrm{C}$ and $15^{\circ} \mathrm{C}$, even if nitrite was absent; however, spore germination and growth readily occurred at $35^{\circ} \mathrm{C}$. Comparison of nitrite effects was best evaluated at $35^{\circ} \mathrm{C}$ as a permissive condition to examine the effects of nitrite treatments. Celery nitrite showed no significant difference from sodium nitrite when used in both low and high-fat hotdogs, and spore outgrowth was only observed after $2-3$ days at $35^{\circ} \mathrm{C}$ compared to hotdogs without nitrite. Application of bacteriocin preparations in the formulation that were effective against Listeria monocytogenes, and moderately inhibitory towards the 3-strain spore mixture of $C$. sporogenes, were not effective in spore control in manufactured hotdogs. The nitrite validation hotdog trials described herein demonstrates that (celery or sodium) nitrite may prevent Clostridium spore germination for 24-48 h even under permissive conditions to help keep processed meat safe.
\end{abstract}

Keywords: nitrite; Clostridium; frankfurters; celery nitrite; sodium nitrite; spore germination; bacteriocin

\section{Introduction}

Clostridium species (C. botulinum, C. perfringens) are well known for their toxigenicity, anaerobic requirement, and ability to produce spores [1]. These characteristics of pathogenic Clostridium spp. are why physical processes (12-D thermal processing of canned vegetables, soups) and chemical deterrents (nitrite in vacuum-packaged cooked meat products) have been defined to prevent such occurrences [1]. Clostridium spp. are capable of producing spores (sporulation) under certain circumstances, and spores in turn, can develop back into bacterial vegetative cells (germination) [2,3]. Most spores of spore-forming bacteria are 
more heat-resistant than the vegetative cells themselves, and those cells that end up in the environment may sporulate, leaving behind a nearly indestructible spore that accumulates in soils. Anything grown in the agricultural environment can potentially have associated spores, whether vegetables or animals grown for human food [4]. Clostridium botulinum produces botulinum neurotoxin during spore germination [3], while Clostridium perfringens causes illness when high levels of vegetative cells are consumed and produce enterotoxin during sporulation in the intestinal tract [5]. Heating foods contaminated with spores during a cooking process further stimulates them to germinate. Since Clostridium spp. are strict anaerobes, heating followed by bottling, canning, or vacuum packaging can have significant consequences if nothing is done to prevent spores from germinating that either prevent toxin formation (i.e., C. botulinum) or prevent higher vegetative cell levels (C. perfringens).

Chemical nitrite is an indispensable ingredient in cooked and vacuum-packaged processed meats. It is responsible for the obvious color changes in cured meats (i.e., the pink color of cured hams and red color of hotdogs). What may not be so obvious to consumers is the main reason for introducing nitrite into cured/processed meats: it inhibits the germination of pathogenic Clostridium spores. Since their spores are commonplace in soils, the process of cooking and vacuum-packaging soil-sourced foods, such as ready-toeat (RTE) meats, introduces both spore-germinating stimulants such as the heating process and anaerobic packaging.

The use of alternatives to sodium nitrite has often been sought because of the tenuous association of sodium nitrite with the generation of nitrosamines, although direct correlation to gastric cancer is somewhat obscure and other factors have not been ruled out $[6,7]$. One alternative that has been offered is 'natural nitrite' (i.e., microbially fermented vegetable-derived nitrate into vegetable nitrite). This was first initiated in the US in response to a product category labelled 'natural' foods whereby artificial ingredients are not allowed (e.g., sodium nitrite) [8,9]. The consumption of vegetables has been considered 'healthy', yet they contain high levels of nitrate that are converted to nitrite in the intestinal tract and are considered the source of $>95 \%$ of consumer exposure to nitrite $[8,10,11]$. For these reasons, the US Department of Agriculture, Food Safety and Inspection Service (USDA-FSIS) allowed the use of 'natural nitrite' generated by microbial fermentation/conversion in 'natural meats' [12]. However, these products must be labeled as "uncured" but can display "no nitrate or nitrite added except those naturally occurring in vegetable extracts". Other alternative ingredients for control of Clostridium sp. in processed meats involve the use of acidulants of fruits (e.g., lemon juice) or dried vinegar powder, as both are considered natural ingredients [13-15]. Bacteriocins have also experienced marketable success as natural antimicrobials for foods [16-18], although nisin is the only bacteriocin that has US-FDA [19] and EU [20] approval for use in certain foods because it had a history of safe use in foods and shown to be nontoxic to humans. Although other bacteriocins may not have US-FDA approval, if they are produced by microorganisms that are generally regarded as safe (GRAS) for use in foods, then the organisms themselves, or the culture supernatants, can be added to foods [21,22]. The vast array of types of processed foods that are available, and the many potential natural ingredients, require extensive validation challenge studies to insure they are effective and safe.

Most food process validation studies are preferably performed with foodborne pathogens, but this requires the procedures to be done in a protected BSL-2 laboratory, and the equipment used is often restricted or dedicated for use with pathogenic microorganisms (or nonedible products) for safety reasons. The use of 'surrogate microorganisms', or those that are closely related to pathogens but are not pathogenic (BSL-1), allows such procedures to be performed more freely in many laboratories, and even directly with real commercial equipment in food manufacturing plants. 'In-plant studies' are often preferred to laboratory test runs because it is often questionable whether the transition from the laboratory to commercial processes provides an equitable scale up. Numerous studies have indicated that C. sporogenes serves as a processing surrogate to proteolytic C. botulinum [23-27]. Brad- 
bury et al. [25] go as far as suggesting that phylogenetic separation of C. botulinum and C. sporogenes is not tenable given the $>85 \%$ match of C. sporogenes PA 3679 to proteolytic C. botulinum strains.

In a prior paper we identified nitrate-reducing bacteria that were capable of fermenting vegetable-derived nitrate to natural vegetable nitrite and discussed the regulatory status of natural nitrite in the US, which is different than in the EU [9]. In this study, the objectives were to characterize three strains of Clostridium sporogenes as surrogate microorganisms for C. botulinum/C. perfringens by retrieving spores for inoculated trials with high and low-fat hot dogs, to compare the effectiveness of sodium nitrite (synthetic) vs. vegetablederived celery nitrite (natural) and determine whether bacteriocins can prevent Clostridium spore germination.

\section{Materials and Methods}

\subsection{Bacterial Cultures and Media}

Clostridium sporogenes ATCC 3584, ATCC 19404, and ATCC BAA-2695 (PA 3679, NCA 3679) were obtained from American Type Culture Collection (Manassas, VA, USA) and used in this study to harvest spores for use as a 3-strain spore inoculum [23,28-31]. Strains of C. sporogenes were grown anaerobically in reinforced Clostridium medium without agar (RCM; HiMedia, Mumbai, India) at $37^{\circ} \mathrm{C}$ in broth tubes or on reinforced Clostridium agar (RCA $+1.5 \%$ agar). Broth tubes with loosely seated caps and agar plates were incubated anaerobically in anaerobe jars (BD Labs, BBL, Franklin Lakes, NJ, USA) using $\mathrm{CO}_{2}$-generating envelopes (AnaeroPack; Fisher Scientific, Atlanta, GA, USA). Dilution of cultures or hotdog samples prior to enumeration on agar plates, was performed in sterile $0.1 \%$ buffered peptone water (BPW).

Bacteriocin-producing (Bac ${ }^{+}$) cultures: Lactococcus lactis FLS1, Lactobacillus curvatus FS47, Lactobacillus curvatus Beef3, Streptococcus sp. 323, Enterococcus faecium FS56-1 and Pediococcus acidilactici Bac3 were isolated and identified in previous studies [32-34]. These cultures were propagated in Lactobacilli MRS broth (BD Labs) at $30^{\circ} \mathrm{C}$. Bacteriocins are generally produced as secondary byproducts and secreted into the medium, accumulating during stationary phase. Individual $\mathrm{Bac}^{+}$cultures were inoculated into $150 \mathrm{~mL}$ of MRS broth and held at $30{ }^{\circ} \mathrm{C}$ and harvested at 20-24 h. Cultures were centrifuged in a Sorvall RC50 Plus (ThermoFisher Scientific, Waltham, MA, USA) for $15 \mathrm{~min}$ at $5^{\circ} \mathrm{C}(12,850 \times g)$ and decanted. The cell-free supernatant (CFS) was collected and frozen at $-20{ }^{\circ} \mathrm{C}$ until use.

\subsection{Antibiotic Assay of Clostridium sporogenes}

Clostridium sporogenes ATCC 3584, ATCC 19404 and ATCC BAA-2695 were tested for innate antibiotic resistance using BD BBL Sensi-Discs (BD Labs) consisting of sterile paper discs impregnated with specific levels of antibiotic [35]. Bacterial lawns were obtained for individual cultures by seeding $0.1 \mathrm{~mL}$ of overnight culture into $10 \mathrm{~mL}$ molten/tempered RCA $(0.75 \%$ agar), mixed and overlaid onto prepoured RCA (1.5\% agar) in large $150-\mathrm{mm}$ Petri dishes as described previously for Salmonella [36]. When the seeded overlay agar layer solidified, antibiotic discs were aseptically dispensed onto the bacterial lawns and the plates were incubated anaerobically overnight at $37^{\circ} \mathrm{C}$. Following incubation, cultures were evaluated for degree of susceptibility based on subjective visual observation of the size of the inhibitory zone around the disc. Zones of various sizes around the discs were indicative of different degrees of sensitivity, and the absence of a zone was deemed as resistant.

Antibiotics examined included Amikacin $(30 \mu \mathrm{g})$, Ampicillin $(10 \mu \mathrm{g})$, Cefazolin $(30 \mu \mathrm{g})$, Cefotaxime $(30 \mu \mathrm{g})$, Cefoxitin $(30 \mu \mathrm{g})$, Cephalothin $(30 \mu \mathrm{g})$, Chloramphenicol $(30 \mu \mathrm{g})$, Chloramphenicol (5 $\mu \mathrm{g})$, Ciprofloxacin (5 $\mathrm{g})$, Clindamycin $(2 \mu \mathrm{g})$, Colistin (10 $\mu \mathrm{g})$, Erythromycin $(15 \mu \mathrm{g})$, Ethionamide (25 ug), Furazolidone (100 ug), Gentamicin (10 $\mu \mathrm{g})$, Isoniazid $(5 \mu \mathrm{g})$, Nalidixic acid $(30 \mu \mathrm{g})$, Nitrofurantoin $(300 \mu \mathrm{g})$, Novobiocin $(5 \mu \mathrm{g})$, Oxacillin $(1 \mu \mathrm{g})$, Penicillin (10 units), Piperacillin (100 $\mu \mathrm{g})$, Rifampin $(5 \mu \mathrm{g})$, Streptomycin $(10 \mu \mathrm{g})$, Streptomycin $(50 \mu \mathrm{g})$, Tetracycline $(30 \mu \mathrm{g})$, Tobramycin $(10 \mu \mathrm{g})$ and Vancomycin $(30 \mu \mathrm{g})$ (BD Labs). 
Antibiotic resistance was confirmed by enumeration on agar by plating individual cultures grown in RCM (without antibiotics) for comparison of quantitative enumeration onto RCA plates, with and without individual antibiotics. Quantitative enumeration was again performed on agar media with a combination of antibiotics instead of individual antibiotics. It is important to ensure the absence of synergistic inhibitory activity when multiple antibiotics are combined, as has been observed elsewhere $[37,38]$. Enumeration of the three strains of C. sporogenes (i.e., with and without antibiotics) was performed in triplicate replication. The use of antibiotics in selective media ensures that microbial enumeration was based on our spore inoculum strains and not from other bacteria/spores that might also be indigenous to the ingredients and spices used in the meat matrix or acquired from nonsterile postprocess handling of hotdogs. This was considered important as no antimicrobials (lactate, diacetate, dried vinegar powder) were added to the hotdogs as commonly done with commercial hotdogs to eliminate confusion on the impact of ingredients on the inhibition of spore germination.

\subsection{Sporulation and Spore Crop Isolation}

Spores from C. sporogenes ATCC 3584, ATCC 19404 and ATCC BAA-2695 were harvested after sporulation in broth and on agar to determine which procedure may provide a better yield of spores (Figure 1). Briefly, for sporulation in broth we used a modification of procedures described by Perkins [39] and Yang et al. [40]. This procedure included anaerobic growth in RCM, transfer to sporulation medium with heat shock, extended anaerobic incubation to induce sporulation, purification with lysozyme treatment, sonication, washing with phosphate buffered saline (PBS), and then purified spores were stored in deionized water and frozen at $-20^{\circ} \mathrm{C}$ until use.

Individual cultures were grown anaerobically overnight in RCM at $37{ }^{\circ} \mathrm{C}$ and transferred as $10 \%$ inoculum to $90 \mathrm{mls}$ of sporulation medium (3\% trypticase, $1 \%$ peptone, $1 \%$ ammonium sulfate), heat shocked at $80{ }^{\circ} \mathrm{C}$ for $15 \mathrm{~min}$ and then incubated anaerobically with gentle shaking ( $180 \mathrm{rpm})$ for $5-6$ days at $30^{\circ} \mathrm{C}$. Sporulation on agar was also performed by anaerobic incubation of individual cultures in $\mathrm{RCM}$ overnight at $37^{\circ} \mathrm{C}$, spread plating each culture on six Petri dishes containing RCA and again incubating anaerobically at $30{ }^{\circ} \mathrm{C}$ for six days. After six days, bacterial lawns on the Clostridium sporulation plates were resuspended with $6 \mathrm{mls}$ of sterile water using a sterile plastic rake and transferred to sterile Oak Ridge tubes. At this point, the remaining procedure was the same for both methods (Figure 1): postsporulation liquid cultures or lawn-resuspended sporulated cells were centrifuged at $12,850 \times g\left(5^{\circ} \mathrm{C}\right)$. The centrifuged pellet of the sporulated cells was decanted and resuspended with sterile PBS $\left(137 \mathrm{mmol} \mathrm{NaCl}, 2.7 \mathrm{mmol} \mathrm{KCl}, 10 \mathrm{mmol} \mathrm{Na} \mathrm{HPO}_{4}\right.$, $\mathrm{pH}$ 7.4). This was repeated three times, after which the final pellet was resuspended with $20 \mathrm{mls}$ of PBS containing lysozyme $(0.5 \mathrm{mg} / \mathrm{mL})$ and incubated at $37^{\circ} \mathrm{C}$ for $2 \mathrm{~h}$. After lysozyme incubation, the washed lysozyme-treated sporulated cells were sonicated for 5 min at high setting in a Branson ${ }^{\text {Tm }}$ ultrasonic bath (Emerson, St. Louis, MO, USA). The sonicated samples were then centrifuged at $2050 \times g$ at $5{ }^{\circ} \mathrm{C}$ for $20 \mathrm{~min}$, decanted, and resuspended with $20 \mathrm{~mL}$ sterile deionized water (this washing step was repeated two more times). The final harvested and concentrated spore crops (i.e., $\sim 1 \times 10^{8} \mathrm{cfu} / \mathrm{mL}$ ) were then distributed into Eppendorf tubes and frozen at $-20^{\circ} \mathrm{C}$ until needed. 


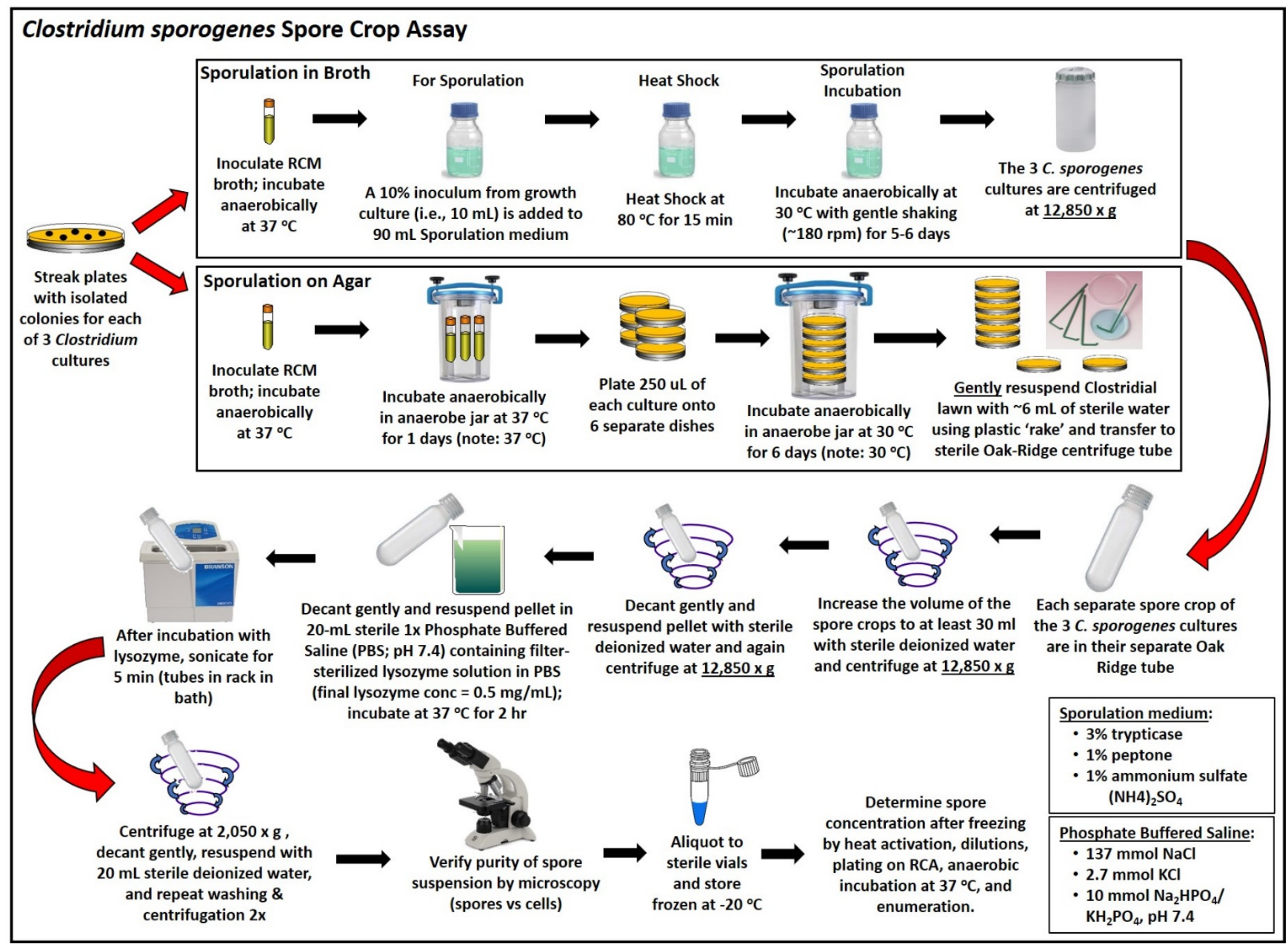

Figure 1. Schematic of two different spore crop assays used in this study to obtain spores for challenge studies with hotdogs. The two methods differ in the way spores are stimulated to germinate, one in broth and the other on agar plates, after which both methods are identical.

\subsection{Electron Microscopy of Clostridium sporogenes Cells and Spores}

Bacteria and spore crops were grown and harvested as described above and were examined by scanning electron microscopy (SEM) at the Oklahoma State University Electron Microscopy Core Facility. SEM procedures were provided by the technical staff (Ms. Lisa Whitworth) as part of a class at the OSU Microscopy Core Facility [41]. Bacteria and spore crops were centrifuged $\left(12,857 \times g, 5{ }^{\circ} \mathrm{C}, 10 \mathrm{~min}\right)$ and resuspended in $0.1 \%$ sterile BPW in preparation for adherence to glass cover slips. Poly-L-lysine precoated German glass cover slips (Neuvitro Corp, Vancouver, WA, USA) were placed in 24-well Corning noncoated plates, and aliquots of culture or spores were spotted (50-200 uL) onto the cover slips and allowed to dry for $30 \mathrm{~min}$. Approximately $200 \mathrm{uL}$ of $2 \%$ glutaraldehyde fixative was added and allowed to react for $2 \mathrm{~h}$ and then rinsed three times with buffered wash for $15 \mathrm{~min}$. Cover slips were then fixed with $1 \%$ osmium tetroxide $\left(\mathrm{OsO}_{4}\right)$ for $1 \mathrm{~h}$ and rinsed three times again with buffered wash for $15 \mathrm{~min}$. The fixed cells/spores were dehydrated by immersing slides in an ethanol series: 50\%, 70\%, 90\%, 95\% for $15 \mathrm{~min}$ each, and then three times with $100 \%$ ethanol for $15 \mathrm{~min}$. Hexamethyldisilazane (HMDS) was used as an alternative to critical point drying by washing twice for $5 \mathrm{~min}$, and then the glass slips were allowed to dry/set overnight [42]. Double-sided carbon tape was used to adhere the slips to the SEM stubs, which were sputter coated with gold-palladium. SEM was then performed on a FEI Quanta 600 FEG ESEM instrument (ThermoFisher Scientific, Hillsboro, OR, USA). 


\subsection{Meat Formulation and Hotdog Manufacture}

In the U.S., hotdogs are often manufactured in high fat and low fat (healthier) versions. Sometimes ingredients can partition awkwardly in different formulations and it is necessary to examine functionality of ingredients when substantial changes are made. Hotdog formulations in this study included low and high fat versions based on FOSS method for fat determination $[43,44]$ (Table 1). The low and high-fat formulations were run as separate trials, and both were run in duplicate replication. Within each fat level formulation, the total common meat for the three sub-batches was mixed with $80 \%$ of the formula water, which contained the spore inoculum (Figure 2A), blended, and separated into three equivalent weight sub-batch meat portions (Figure 2B). The remaining $20 \%$ formula water was also split into three equal portions to which were added the additional unique ingredients of the three different sub-batch meat portions. These were then further mixed/emulsified into the three respective sub-batches. The three sub-batch portions represented (a) control (no nitrite), (b) sodium nitrite and sodium erythorbate, and (c) celery nitrite and cherry extract as shown in Table 1 under both the low and high-fat formulations. Celery nitrite (VegStable) and cherry extract (natural erythorbate analogue) were obtained from Florida Food Products, Eustis, FL, USA. In this manner, the spore inoculum could be added to the common bulk of the meat (via $80 \%$ of formula water) while it was being ground and mixed, and then divided into three equal portions. The unique ingredients were then added via the remaining $20 \%$ water that was split between the three meat sub-portions.

Table 1. Hotdog ingredient formulation for low and high-fat hotdogs.

\begin{tabular}{|c|c|c|c|c|c|c|c|}
\hline Ingredient & Formulation \% & \multicolumn{3}{|c|}{$\begin{array}{c}\text { Low-Fat } \\
\text { Formulation }\end{array}$} & \multicolumn{3}{|c|}{$\begin{array}{l}\text { High-Fat } \\
\text { Formulation }\end{array}$} \\
\hline Beef & $72.69 \%$ & \multicolumn{3}{|c|}{ (Beef 90, beef 50) } & \multicolumn{3}{|c|}{ (Beef 80, beef 50) } \\
\hline Ice/Water & $24.92 \%$ & \multicolumn{3}{|c|}{$(80 \%+20 \%$ portions $) *$} & \multicolumn{3}{|c|}{$(80 \%+20 \%$ portions $) *$} \\
\hline \multicolumn{8}{|l|}{$\begin{array}{c}\text { AC Legg Bologna/Frank Seasoning w/o } \\
\text { Erythorbate }\end{array}$} \\
\hline \multirow{2}{*}{$\begin{array}{l}\text { Salt, dextrose, MSG }(2.91 \%) \text {, onion powder, } \\
\text { garlic powder, spice extracts, tricalcium } \\
\text { phosphate }\end{array}$} & $2.14 \%$ & & & & & & \\
\hline & & CTL & Nitrite & Celery & CTL & Nitrite & Celery \\
\hline Prague Powder (6.25\% sodium nitrite) & & - & $0.18 \%$ & - & - & $0.18 \%$ & - \\
\hline Sodium Erythorbate & & - & $0.04 \%$ & - & - & $0.04 \%$ & - \\
\hline Celery Powder (2.34\% sodium nitrite) & & - & - & $0.48 \%$ & - & - & $0.48 \%$ \\
\hline Cherry Powder (17\% ascorbic acid) & & - & - & $0.20 \%$ & - & - & $0.20 \%$ \\
\hline Alkaline Phosphate & $0.25 \%$ & & & & & & \\
\hline Total: & $100 \%$ & & & & & & \\
\hline
\end{tabular}

Restricted ingredients (maximum permitted levels):

Sodium nitrite $(\max =156 \mathrm{ppm})$

Sodium erythorbate $(\max =547 \mathrm{ppm})$

Ascorbic acid $(\max =468 \mathrm{ppm})$

Alkaline phosphate $(\max =0.5 \%)$

$0.34 \%$

${ }^{*}$ Note: Spores were added in the $80 \%$ portion of water that was used for mixing the entire common batch meat mixture for either the low or high-fat formulations. After mixing the common meat batch, it was split into three equal subportions. The remaining $20 \%$ water was also split into three portions and used to solubilize and add the unique ingredients to each sub-batch portion (control, sodium nitrite/erythorbate, celery nitrite/cherry powder) within each low/high-fat formulation. 'Beef $90^{\prime}$, 'beef $80^{\prime}$, and 'beef 50 ' represent $90 \%$ beef $(10 \%$ fat), $80 \%$ beef $(20 \%$ fat), and $50 \%$ beef $(50 \%$ fat $)$, respectively. Ingredient components listed with a dash $(-)$ indicates absence of the ingredient component. Sub-batch heading abbreviations: CTL (control); Nitrite (sodium nitrite); Celery (celery nitrite). 


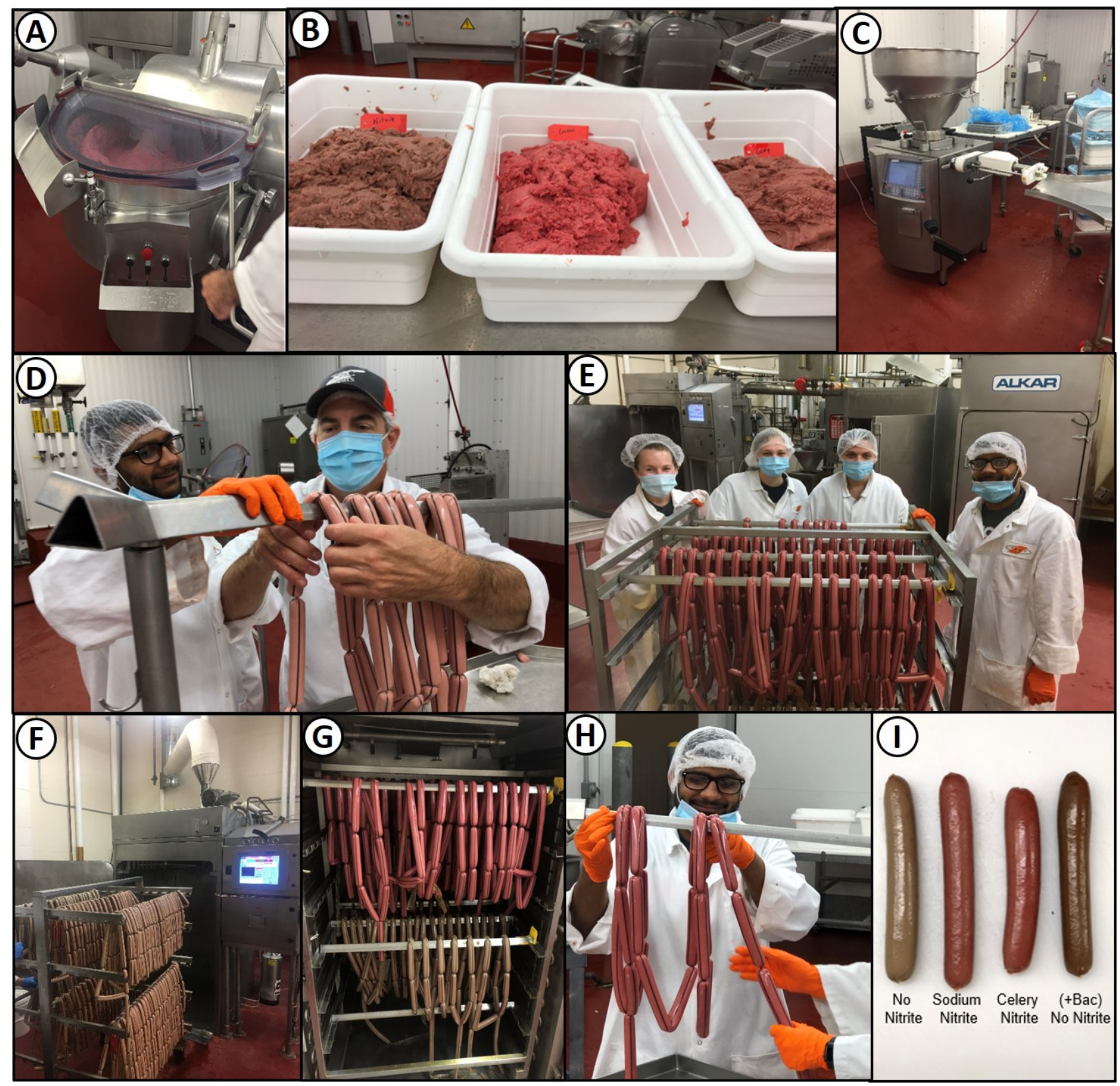

Figure 2. Manufacture of hotdogs in the Meat Pilot Plant of the Robert M. Kerr Food \& Agricultural Products Center at OSU. A uniform base of meat was emulsified for use in hotdogs with $80 \%$ of the required water (containing spores), divided into different batches into which the final ingredients differentiating the various treatments were added with the remaining $20 \%$ of water (i.e., control with no nitrite, celery nitrite, or sodium nitrite). (Panel A), bowl chopper used to grind the meat components and make emulsions. (Panel B), various batches of meat emulsion representing the various treatments. (Panel C), stuffing equipment used to stuff the meat emulsion into casings. (Panel D), investigators and workers wrapping encased hotdogs onto holding racks and dollies. (Panel E), one of several finished holding racks with length of raw encased hotdogs prior to cooking. (Panel F), holding rack entering the Alcar oven. (Panel G), rack of hotdogs positioned in the Alkar oven. (Panel H), removing encased hotdogs from rack. (Panel I), hotdogs after cooking and removal from casings. After cooking, hotdogs were cooled by chilled brine spray, peeled, vacuum packaged, and sent directly for shelf-life storage in incubators set for $5{ }^{\circ} \mathrm{C}, 15^{\circ} \mathrm{C}$ and $35^{\circ} \mathrm{C}$. Some batches were frozen at $-20^{\circ} \mathrm{C}$ for $2 \mathrm{~h}$ prior to incubated shelf life to determine if freezing affects spore germination and outgrowth. 
Hotdogs were manufactured with the formulation described above and listed in Table 1. No antimicrobials were added (i.e., lactate, diacetate) as is commonly done in commercial frankfurters so as not to confuse the source of antimicrobial activity of nitrite during assessment of spore germination. Emulsions were stuffed into Viscofan 24 (Viscofan, Montgomery, AL, USA) casings (Figure 2C-E) and thermally processed (cooked) in an electric-fired, batch oven (Alkar, DEC International, WA, USA) to an internal temperature of $88^{\circ} \mathrm{C}\left(190^{\circ} \mathrm{F}\right)$ (Figure 2F,G). After cooking (Figure $\left.2 \mathrm{H}\right)$, hotdogs in casings were chilled with a cold water rinse and then peeled using a peeling machine (PS760L Peeler, Linker Machines, Rockaway, NJ, USA). The formulations described in Table 1 were used for evaluation of spore germination when sodium nitrite, celery nitrite, or control hotdogs (spores, but without nitrite) were used. The spore crop inoculum was comprised of a mixture of three separate preparations of spore crops and adjusted so that each was approximately $1 \times 10^{8} \mathrm{cfu} / \mathrm{mL}$ when mixed. This allowed a 5-log dilution during addition to the formulation to result in approximately $1 \times 10^{3} \mathrm{cfu} / \mathrm{gm}$ in the finished hotdog. The hotdogs manufactured by these different protocols were kept separate from each other, vacuum packaged in 3 mil high oxygen barrier pouches (Prime Source, Bunzyl Distribution USA, St. Louis, MO, USA), chilled down to refrigeration temperature (nonfrozen) and immediately incubated for shelf-life storage. Low-fat hotdogs were stored for 18-20 weeks at refrigerated $\left(5^{\circ} \mathrm{C}\right)$ and accelerated shelf life $\left(15^{\circ} \mathrm{C}\right)$ temperatures, and eight days for extreme temperature storage $\left(35^{\circ} \mathrm{C}\right)$. Trials with high fat hotdogs stored at $15^{\circ} \mathrm{C}$ were cut short at eight weeks when it became clear from the other trials that even this temperature was not sufficient to allow outgrowth of spores. Hotdogs samples that were frozen after packaging to evaluate the effect of freezing on spore germination were held at $-20^{\circ} \mathrm{C}$ immediately after manufacture/packaging. These hotdogs were then placed at $35^{\circ} \mathrm{C}$ for shelf-life testing to see if freezing interrupted spore germination. Length of shelf-life storage of bacteriocin-containing hotdogs was evaluated depending on whether any effect was observed.

The application of bacteriocins that previously demonstrated inhibition of $L$. monocytogenes was also examined against $C$. sporogenes spores in hotdogs by addition of bacteriocin culture supernatants in meat emulsions during hotdog manufacture as described previously [45]. The bacteriocin-containing culture preparations were added as part of the $80 \%$ water portion of the formulation that was added to assist the grinding of the raw meat. The bacteriocins are heat stable and able to withstand cooking temperatures and still retain antimicrobial activity $[45,46]$. Cell-free supernatants (CFS) were obtained $(150 \mathrm{~mL} /$ culture) and mixed from six bacteriocin-producing cultures, described previously, that were effective against $L$. monocytogenes. Bacteriocins and corresponding activity levels (AU) were obtained from Lc. lactis FLS1 (3200 AU/mL), L. curvatus FS47 (51,200 AU/mL), L. curvatus Beef3 (12,800 AU/mL), Streptococcus sp. 323 (6400 AU/mL), E. faecium FS56-1 (12,800 AU/mL) and $P$. acidilactici Bac3 $(25,600 \mathrm{AU} / \mathrm{mL})$. Cultures were inoculated at $1 \%$ inoculum into MRS broth, incubated overnight at $35^{\circ} \mathrm{C}$ for $18-24 \mathrm{~h}$, harvested by centrifugation $\left(8000 \times g, 5^{\circ} \mathrm{C}\right)$, decanted, and mixed in equal volume proportions. The mixed CFS was $\mathrm{pH}$-adjusted to 6.0 (we observed that CFS added at $<\mathrm{pH} 6.0$ may affect hotdog protein-emulsion setting during cooking, so we adjusted it to $\mathrm{pH}$ 6.0). The mixed CFS bacteriocin cocktail was tested for inhibitory activity by spot-plating on fresh lawns of a three-strain mixture of C. sporogenes RCM agar plates and incubated anaerobically at $30^{\circ} \mathrm{C}$ for $16-18 \mathrm{~h}$. The agar plates were then checked for the appearance of inhibition zones indicating bacteriocin activity. Bacteriocin-containing CFS (adjusted to $\mathrm{pH}$ 6.0) was used to displace water added to the meat mixture before mixing (i.e., $1 \mathrm{~L}$ of mixed bacteriocin CFS per $18 \mathrm{~kg}$ of formulation). The bacteriocin formulation (not shown in Table 1) resembled the 'control' sub-batch formulations (i.e., nitrite and accelerator not added; Table 1) except for the addition of the bacteriocin CFS cocktail in place of the added water. 


\subsection{Statistical Analysis}

Each experimental challenge trial was performed in duplicate replication with three samples tested per sampling period within each replication $\left(n_{\text {total }}=6\right)$ in accordance with validation testing criteria established by the NACMCF [47] and accepted by USDAFSIS [48]. All replications were performed as autonomous and separate experiments using separately inoculated cultures, separately prepared plating media and different lot of meat ingredients. Data are presented as the mean of multiple replications with standard deviation of the mean represented by error bars. Comparisons of growth with, and without, antibiotics were performed by one way analysis of variance (ANOVA). Statistical analysis of timed series data was done using repeated measures one way analysis of variance (RM-ANOVA) and the Holm-Sidak test for pairwise multiple comparisons to determine significant differences. For both types of analyses, data or treatments with different letters are significantly different $(p<0.05)$; data or treatments with the same letter are not significantly different $(p>0.05)$.

\section{Results and Discussion}

\subsection{Antibiotic Resistance of Clostridium sporogenes ATCC 3584, ATCC 19404, and ATCC BAA-2695}

Clostridium sporogenes ATCC 3584, ATCC 19404 and ATCC BAA-2695 (PA 3679) were examined for indigenous antibiotic resistance on various antibiotics using the simple BD Sensi-Disc assay on agar plates. Based on the pattern of sensitivity or resistance, we identified common antibiotics that all three strains were resistant to that could serve as selective agents in standard RCA media (Table 2). Antibiotic resistance or susceptibility were categorized subjectively based on observed zone sizes around the discs as sensitive (S), very sensitive (VS) or extremely sensitive (ES). Cultures with discs without zones were considered resistant $(\mathrm{R})$ to those antibiotic levels (Table 2).

Based on the antibiotic resistance profiles in Table 2, we tested several combinations of antibiotics that could be added to media for selective enumeration of $C$. sporogenes used in this study. RCA medium containing oxacillin $(0.5 \mathrm{ug} / \mathrm{mL})$ and colistin $(5 \mathrm{ug} / \mathrm{mL})$ gave equivalent enumeration when the three strains of $C$. sporogenes were tested individually on media with, and without, antibiotics with no significant differences $(p<0.05)$. This combination would provide suppression of any background organisms that might be present when we plated samples of nonsterile hotdogs held for extended periods of shelf-life, considering hotdogs were made without antimicrobials that would typically suppress some contaminants during shelf life. Oxacillin and colistin allowed quantitative enumeration of $C$. sporogenes from the various hotdog emulsions used in this study (data not shown). 
Table 2. Antibiotic disk assay using B-D Sensi-Discs on lawns of strains of C. sporogenes used in this study to determine susceptibility or resistance ( $R$, resistant; $S$, sensitive; VS, very sensitive; ES, extremely sensitive).

\begin{tabular}{|c|c|c|c|c|c|c|c|c|c|c|c|}
\hline $\begin{array}{c}\text { Sensi-Disc } \\
\text { Designation: }\end{array}$ & $\mathrm{OX} / 1$ & CL/10 & $\mathrm{AN} / 30$ & $\mathrm{NN} / 10$ & $\mathrm{INH} / 5$ & $\mathrm{EA} / 25$ & $\mathrm{~S} / 50$ & $\mathrm{VA} / 30$ & $\mathrm{RA} / 5$ & $\mathrm{NA} / 30$ & $\mathrm{NB} / 5$ \\
\hline Sensi-Disc Dose $(\mu \mathrm{g})$ : & 1 & 10 & 30 & 10 & 5 & 25 & 50 & 30 & 5 & 30 & 5 \\
\hline C. sporogenes 3584 & $\mathrm{R}$ & $\mathrm{R}$ & $\mathrm{R}$ & $\mathrm{R}$ & $\mathrm{R}$ & $\mathrm{R}$ & VS & VS & VS & VS & $S$ \\
\hline C. sporogenes 19404 & $\mathrm{R}$ & $\mathrm{R}$ & $\mathrm{R}$ & $\mathrm{R}$ & $\mathrm{R}$ & $\mathrm{R}$ & $S$ & VS & ES & VS & $S$ \\
\hline $\begin{array}{l}\text { C. sporogenes } \\
\text { BAA-2695 }\end{array}$ & $\mathrm{R}$ & $\mathrm{R}$ & $\mathrm{R}$ & $\mathrm{R}$ & $\mathrm{R}$ & S & S & VS & VS & VS & $S$ \\
\hline $\begin{array}{l}\text { Sensi-Disc } \\
\text { Designation: }\end{array}$ & FX/100 & $\mathrm{F} / \mathrm{M} / 300$ & $\mathrm{CF} / 30$ & GM/10 & $\mathrm{E} / 15$ & $\mathrm{C} / 5$ & $\mathrm{CZ} / 30$ & FOX/30 & $\mathrm{TE} / 30$ & $\mathrm{AM} / 10$ & \\
\hline Sensi-Disc Dose $(\mu \mathrm{g})$ : & 100 & 300 & 30 & 10 & 15 & 5 & 30 & 30 & 30 & 10 & \\
\hline C. sporogenes 3584 & ES & ES & ES & $S$ & VS & VS & ES & VS & ES & ES & \\
\hline C. sporogenes 19404 & ES & ES & ES & $S$ & VS & VS & VS & VS & ES & ES & \\
\hline $\begin{array}{l}\text { C. sporogenes } \\
\text { BAA-2695 }\end{array}$ & ES & ES & ES & $S$ & VS & VS & ES & VS & ES & ES & \\
\hline
\end{tabular}

Antibiotics: OX, oxacillin; CL, colistin; AN, amikacin; NN, tobramycin; INH, isoniazid; EA, ethionamide; S, streptomycin; VA, vancomycin; RA, rifampin; NA, nalidixic acid; NB, novobiocin; FX, Furazolidone; F/M, nitrofurantoin; CF, cephalothin; GM, gentamycin; E, erythromycin; C, chloramphenicol; CZ, cefazolin; FOX, cefoxitin; TE, tetracycline; AM, ampicillin.

\subsection{Scanning Electron Microscopy of Clostridium sporogenes Cells and Spores}

The C. sporogenes strains were examined by Scanning Electron Microscopy (SEM) at the OSU Electron Microscope Core Facility. Bacterial cell images show differences when grown anaerobically on agar (i.e., long rods; data not shown) vs. broth (short rods; Figure 3A). After extended sporulation, a great proportion of rods showed terminal club-shaped extensions typical of terminal endospores (Figure 3B,C), and harvested spores were mostly found to contain exosporium spore coats (Figure 3D,E) with occasional observation of some liberated spores (Figure 3E,F). Almost all of our purified spore preparations were exosporiacontaining spores (Figure 3D,E). On-agar vs. in-broth sporulation were examined, and recovery of spores from sporulation in broth achieved as high or higher spore counts than recoveries from sporulation on agar surfaces. Broth preparations were cleaner, since harvesting sporulated cells from agar surfaces had a tendency to recover agar. Therefore, the agar surface method of sporulation was abandoned in favor of sporulation in broth.

The exosporia we observed were identical to those observed by Janganan et al. (2016) in C. sporogenes NCIMB 701792 [49]. They investigated the protein composition of the C. sporogenes exosporium and identified three cysteine-rich proteins in C. sporogenes that are homologues sharing significant homology to C. botulinum Group 1 strains [49]. CalderonRomero et al. (2018) subsequently found similar and unique (CdeM) cysteine-rich proteins in C. difficile, using mutagenesis to implicate their likely involvement in C. difficile pathogenesis [50]. 


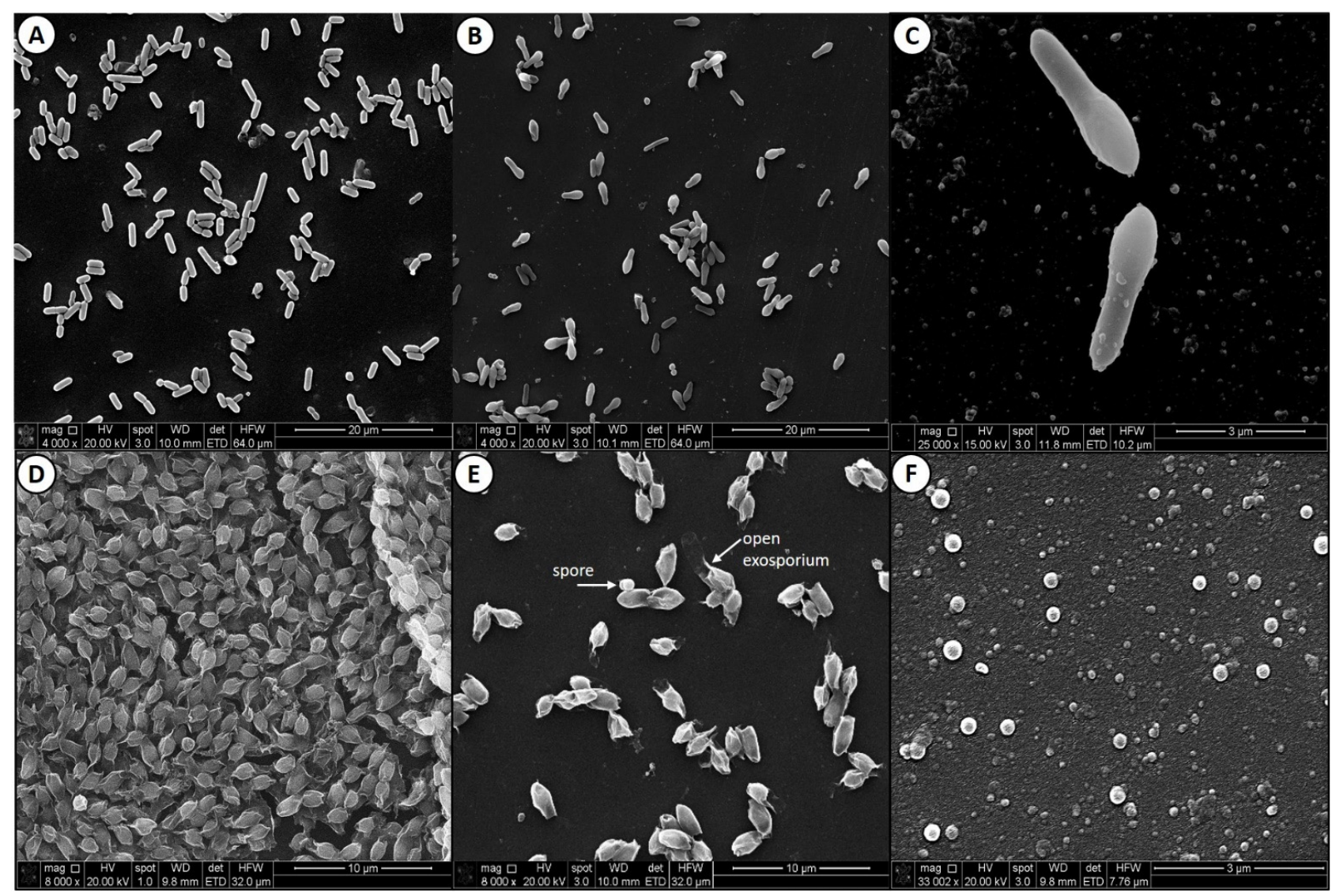

Figure 3. Examination of Clostridium sporogenes by Scanning Electron Microscopy (SEM) at the OSU Electron Microscopy Core Facility. (Panel A), C. sporogenes vegetative cells grown in broth. (Panel B), vegetative cells showing bulging from development of terminal endospores. (Panel C), close-up of cells with terminal endospores. (Panel D), concentrated aggregate of harvested spores within an exosporium coat. (Panel E), dispersed exosporia containing spores. (Panel F), isolated spores.

\subsection{Heated vs. Unheated Spore Crops}

Spore crops were evaluated for enumeration with and without heating $\left(80^{\circ} \mathrm{C}, 15 \mathrm{~min}\right)$. No significant difference $(p<0.05)$ was found between heated and unheated spore crops for each of the three strains of $C$. sporogenes used in this study (Figure 4). This indicates that spores present in hotdog samples during extended shelf-life after cooking, would not need a heat activation step to induce germination and growth into vegetative cells. Counts obtained by direct plating of sample would be representative of both vegetative cells and spores present in the samples. Since the hotdogs were cooked, the initial counts from hotdogs immediately after cooking were representative of the spore load formulated during manufacture, while subsequent higher counts were representative of outgrowth from those spores. Microbial platings on media containing antibiotics precluded the presence of other microorganisms that would otherwise occur on nonselective media and interfere with enumeration of the added inoculum challenge organisms. 


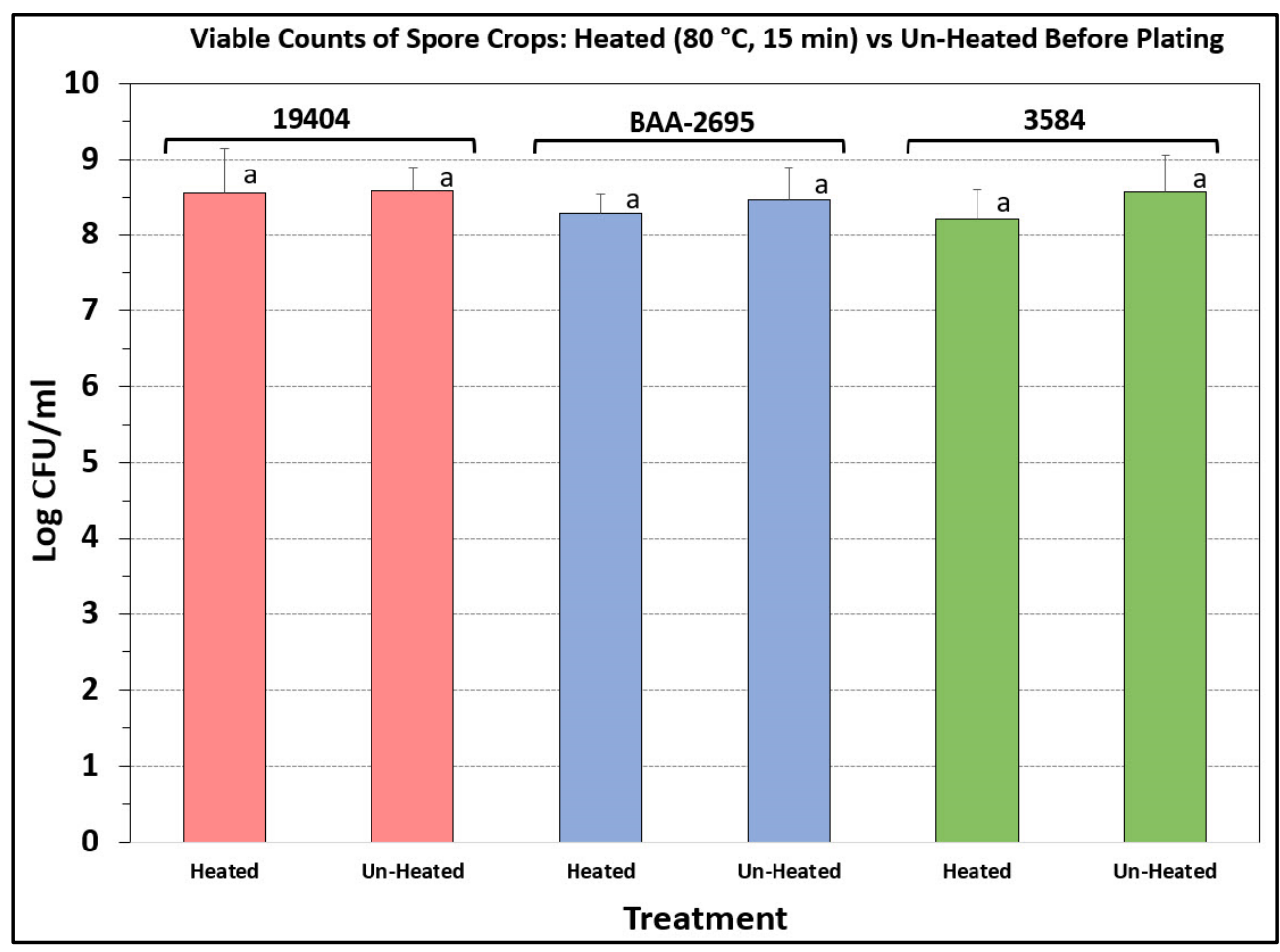

Figure 4. Comparison of heated $\left(80^{\circ} \mathrm{C}, 15 \mathrm{~min}\right)$ and unheated spore crops for each strain used in this study. Data bars are the means of triplicate samples. Treatments for each strain were compared by ANOVA using the Holm-Sidak test to determine significant differences; treatments with different letters are significantly different $(p<0.05)$. Treatments with the same letter are not significantly different $(p>0.05)$.

\subsection{Low-Fat Hotdogs Challenged with Spores from Clostridium sporogenes}

Hotdogs made without nitrite (controls, bacteriocin) produced brown-colored hotdogs while those made with celery or sodium nitrite were a typical reddish color (Figure 2I). Early applications of in-product culture-dependent conversion of vegetable nitrate to nitrite were prone to strain variations in nitrate reductase activity that could lead inconsistency of nitrite levels in products [51,52]. In recent years, such inconsistencies have been eliminated by ingredient manufacturers who use fermentation with microbial cultures to preconvert nitrate to nitrite, generate a dried extract or powdered product, and standardize the level of vegetable nitrite for consistent use in the industry, as was used in this study.

The data shows that no outgrowth of spores occurred at either $5{ }^{\circ} \mathrm{C}$ or $15{ }^{\circ} \mathrm{C}$ for 18-20 weeks with either sodium or celery nitrite (and even without nitrite) as the graph curves of data were fairly steady (Figure 5). In every study we performed, samples from hotdogs with either sodium nitrite or celery nitrite were approximately $0.5-\log$ lower than samples from hotdogs manufactured without nitrite (controls) (Figure 5A,B). We interpret this to suggest that heating in the presence of nitrite, whether sodium or celery nitrite, is inhibitory to the spores or prevents some of them from germinating. All samples were made from the same batch of meat matrix that was inoculated with the same spore crop, mixed and then divided into different batch groups dependent on further addition of the $20 \%$ remaining water from the formulation (i.e., control water, water containing sodium nitrite, or water containing celery nitrite). Since the hotdogs were cooked, the initial counts were due solely to the spores and it is only the samples without nitrite that plate out at higher levels. Such differences in higher spore counts in hotdog samples without nitrite (or with nitrate/starter culture) vs. conventional nitrite have been observed by others $[13,53,54]$. 


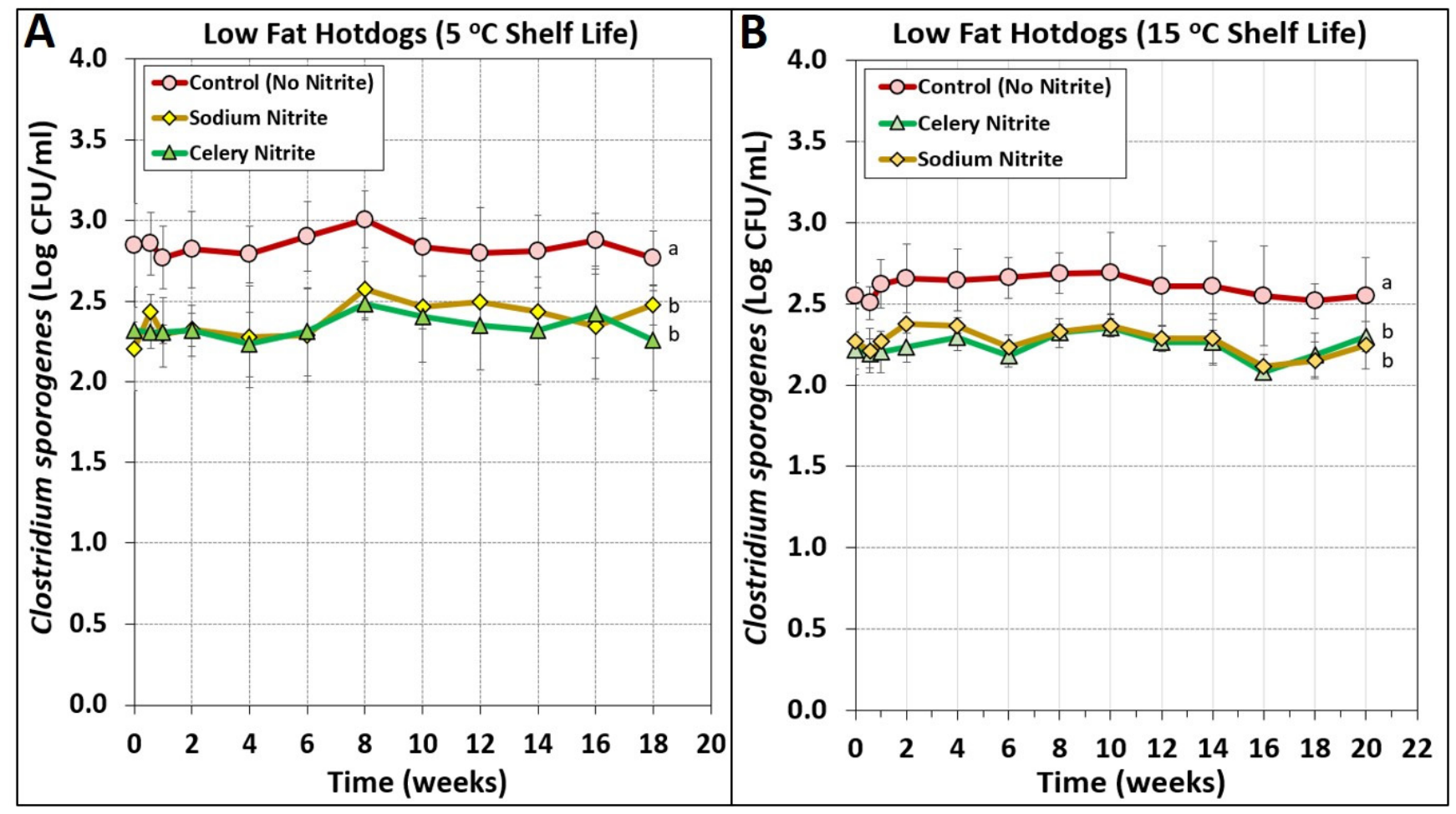

Figure 5. Sampling of low-fat hotdogs manufactured without nitrite (Control), with sodium nitrite or with celery nitrite held at $5{ }^{\circ} \mathrm{C}$ (Panel A) or $15{ }^{\circ} \mathrm{C}$ (Panel B) for 18-20 weeks after cooking. Data points are the means of triplicate samples from each of two replications $(n=6)$. Treatments were analyzed by RM-ANOVA using the Holm-Sidak test for pairwise multiple comparisons to determine significant differences. Treatments with different letters are significantly different $(p<0.05)$. Treatments with the same letter are not significantly different $(p>0.05)$.

Although $15{ }^{\circ} \mathrm{C}$ is considered an abuse temperature for accelerated shelf-life studies for some pathogens, it is not effective to demonstrate growth of $C$. sporogenes, because even samples without nitrite (i.e., controls) did not show outgrowth at either $5^{\circ} \mathrm{C}$ or $15^{\circ} \mathrm{C}$, even after 20 weeks of storage (Figure 5). A higher abuse temperature $\left(35^{\circ} \mathrm{C}\right)$ was examined for use as a 'permissive' temperature assay to allow spore outgrowth in hotdogs (Figure 6A) and provide for better impact on spore germination and outgrowth. Similar results were obtained previously by Hong et al. (2016) whereby spores of C. sporogenes inoculated into ground beef and cooked did not grow at holding temperatures of $15^{\circ} \mathrm{C}$ or below, but did grow between $20^{\circ} \mathrm{C}$ and $47^{\circ} \mathrm{C}$ [55].

We demonstrated a significant difference between control hotdogs made without nitrite vs. experimental hotdogs made with either celery or sodium nitrite (Figure 6A). However, there was no significant difference in spore germination and growth between celery nitrite and sodium nitrite formulated to the same nitrite concentration (Figure 6A). One batch of hotdogs was vacuum-packaged and immediately frozen $\left(-20^{\circ} \mathrm{C}\right)$ for $>2 \mathrm{~h}$ after cooking to try to arrest biochemical reactions in spores stimulated by cooking, and then were placed at $35^{\circ} \mathrm{C}$ (Figure $6 \mathrm{~B}$ ). This treatment may have only slightly reduced their rate of outgrowth compared to samples that were not frozen (Figure 6A). Since we did not observe any effect on spore germination when low-fat hotdogs were frozen immediately after cooking and then incubated at permissive temperatures $\left(35^{\circ} \mathrm{C}\right)$, we did not pursue freezing with high-fat hotdogs. However, the presence of either sodium or celery nitrite in hotdogs, both formulated to the same level of nitrite, may have provided several days of protection from outgrowth to higher numbers even when held at $35^{\circ} \mathrm{C}\left(95^{\circ} \mathrm{F}\right)$. Nitrite is meant to prevent spore germination and provide safety from accidental/unintended temperature abuse that could occur in products that have especially long and extended shelf-lives. 


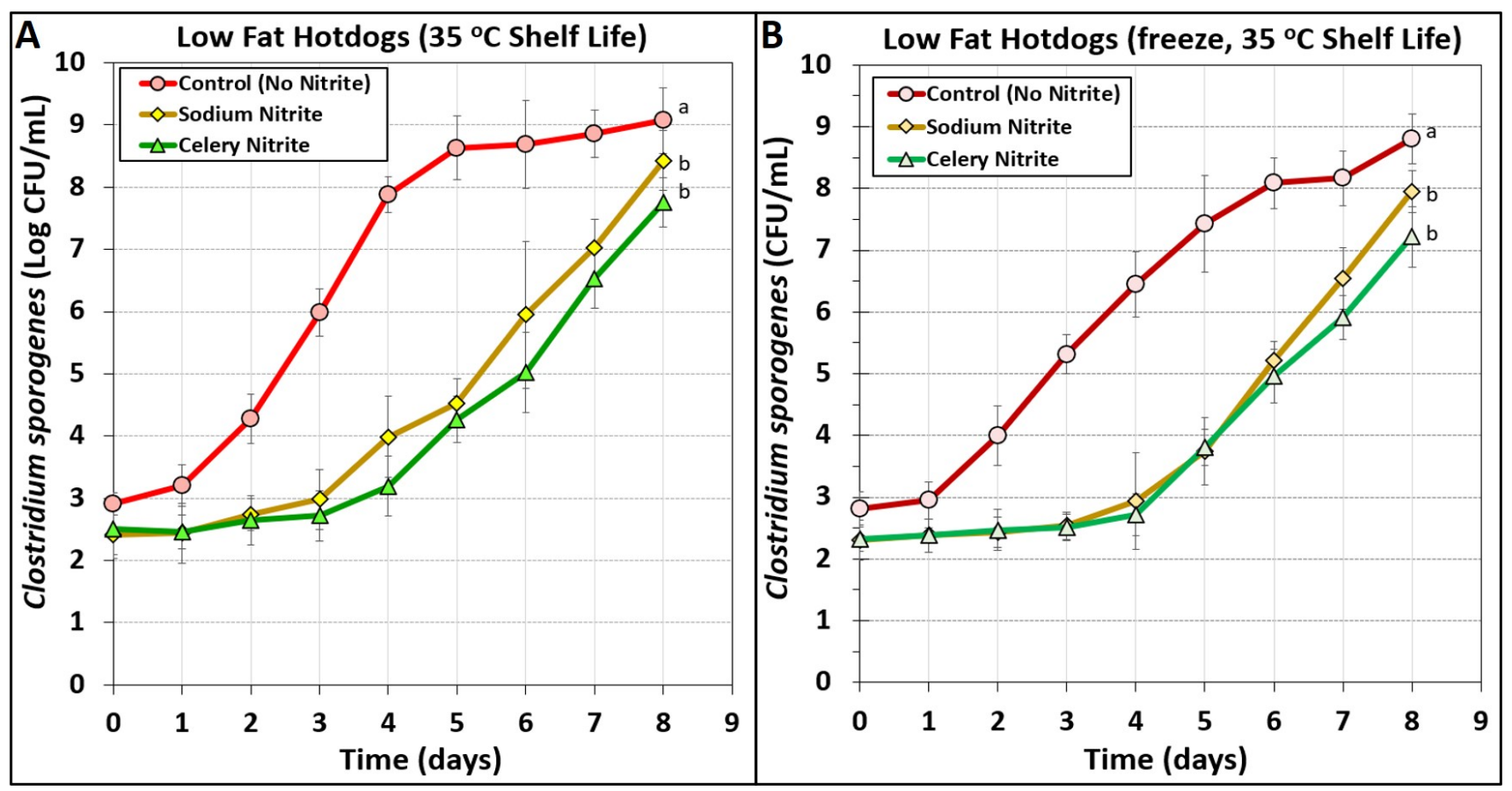

Figure 6. Sampling of low-fat hotdogs manufactured without nitrite (Control), with sodium nitrite, or with celery nitrite held at $35^{\circ} \mathrm{C}$ after cooking for up to eight days of storage. This was the 'permissive' assay to allow spore germination and vegetative cell growth to evaluate effectiveness of nitrite in preventing spore germination. (Panel A), hotdogs were transferred directly to $35^{\circ} \mathrm{C}$ incubators after cooking/vacuum packaging. (Panel B), hotdogs were immediately frozen $\left(-20^{\circ} \mathrm{C}\right)$ for $2 \mathrm{~h}$ after cooking/vacuum packaging and then transferred to $35^{\circ} \mathrm{C}$ incubators. Treatments are the means of triplicate samples from each of two replications $(n=6)$. Treatments were analyzed by RM-ANOVA using the Holm-Sidak test for pairwise multiple comparisons to determine significant differences. Treatments with different letters are significantly different $(p<0.05)$. Treatments with the same letter are not significantly different $(p>0.05)$.

\subsection{Manufacturing of High-Fat Hotdogs Challenged with Spores from C. sporogenes}

As with low-fat hotdogs, high-fat hotdogs made without nitrite (controls, bacteriocins) were 'brownish' in color as opposed to a reddish color when celery/sodium nitrite plus the appropriate accelerant (cherry extract, erythorbate) was present (Figure 2I). The data with high-fat hotdogs again shows that no growth occurred at either $5^{\circ} \mathrm{C}$ (for 18 weeks) or $15^{\circ} \mathrm{C}$ for eight weeks, even when nitrite was not included in the meat matrix (for this reason, the $15^{\circ} \mathrm{C}$ study was cut short at eight weeks). However, spore outgrowth was demonstrated at the permissive incubation shelf-life temperature of $35^{\circ} \mathrm{C}\left(95^{\circ} \mathrm{F}\right)$. Outgrowth started immediately within the first $24 \mathrm{~h}$ in control hotdogs, but in samples with either sodium nitrite or celery nitrite, held at $35^{\circ} \mathrm{C}$, outgrowth was prevented for up to two days even when held at $35^{\circ} \mathrm{C}\left(95^{\circ} \mathrm{F}\right)$. All treatments again showed significant differences $(p>0.05)$ in initial numbers between control samples without nitrite (higher counts) than those with sodium or celery nitrite (lower counts) (Figure 7A-C). 

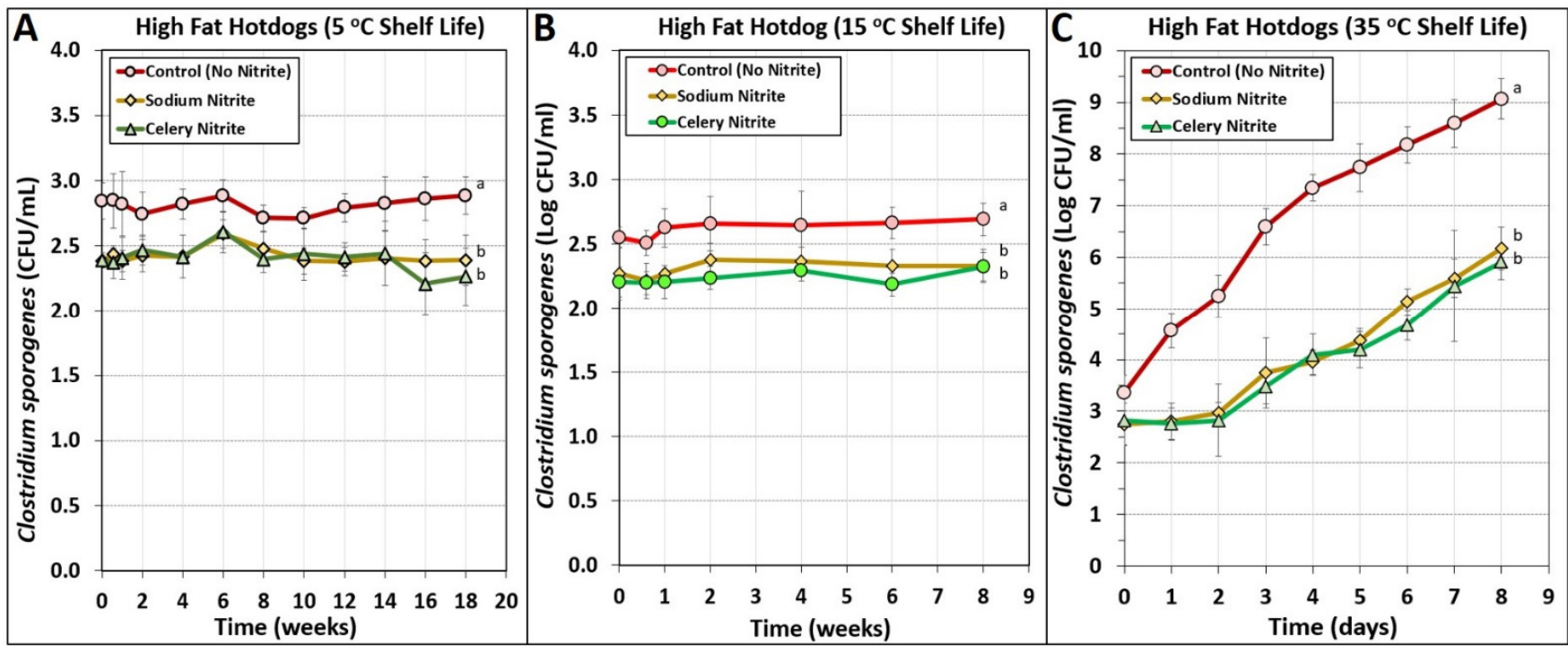

Figure 7. Sampling of high-fat hotdogs manufactured without nitrite (Control), with sodium nitrite, or with celery nitrite held at $5{ }^{\circ} \mathrm{C}$ (Panel A), $15^{\circ} \mathrm{C}$ (Panel B), or $35^{\circ} \mathrm{C}$ (Panel C) after cooking. Treatments are the means of duplicate replications testing triplicate samples at each time period $\left(n_{\text {total }}=6\right)$. Treatments were analyzed by RM-ANOVA using the Holm-Sidak test for pairwise multiple comparisons to determine significant differences. Treatments with different letters are significantly different $(p<0.05)$. Treatments with the same letter are not significantly different $(p>0.05)$.

\subsection{Manufacturing of Low Fat Hotdogs Containing Bacteriocins Challenged with Spores from C. sporogenes}

No effect was observed from added bacteriocin preparations at $15{ }^{\circ} \mathrm{C}$ with either low or high-fat hotdogs (Figure $8 \mathrm{~A}, \mathrm{~B}$ ). When tested with low-fat hotdogs stored at $35^{\circ} \mathrm{C}$, the bacteriocin-containing hotdogs showed no significant difference than control hotdogs made without nitrite while nitrite-containing hotdogs demonstrated the typical 2-3 days of control before outgrowth started to occur, as was observed earlier (Figure 8C). Further testing of the individual bacteriocins from our bacteriocin mixture on each of the three individual strains of $C$. sporogenes, we only found two of the six bacteriocins had significant inhibitory activity towards only one of the strains of $C$. sporogenes (data not shown). Although the bacteriocin mixture showed inhibitory activity against $C$. sporogenes in spot-assays on agar lawns, the activity was insufficient when added to hotdogs. In hindsight, these bacteriocins were originally selected due to their high activity against L. monocytogenes. In other studies with bacteriocins, investigators examined nisin as a replacement or complement to nitrite in processed meats and found strain-specific inhibitory activity [56,57]. However, as a group, Clostridium spp. are relatively insensitive to nisin [58,59]. A more effective approach may be to develop a bacteriocin-based biopreservative for Clostridium spp. by screening for bacteriocins that specifically target Clostridium spp., as was done for L. monocytogenes [45,46]. Han et al. (2014) identified bacteriocins produced by Enterococcus faecalis with activity against $C$. perfringens that also showed activity against $L$. monocytogenes for applications in animal feed [60]. In a prior study, we identified $22 \mathrm{Bac}^{+}$strains among four species of Enterococcus sp. $[33,34]$ that might serve as a first step in further studies examining the activity of bacteriocins against Clostridium sp. in processed meats in comparison to sodium or natural nitrite. 

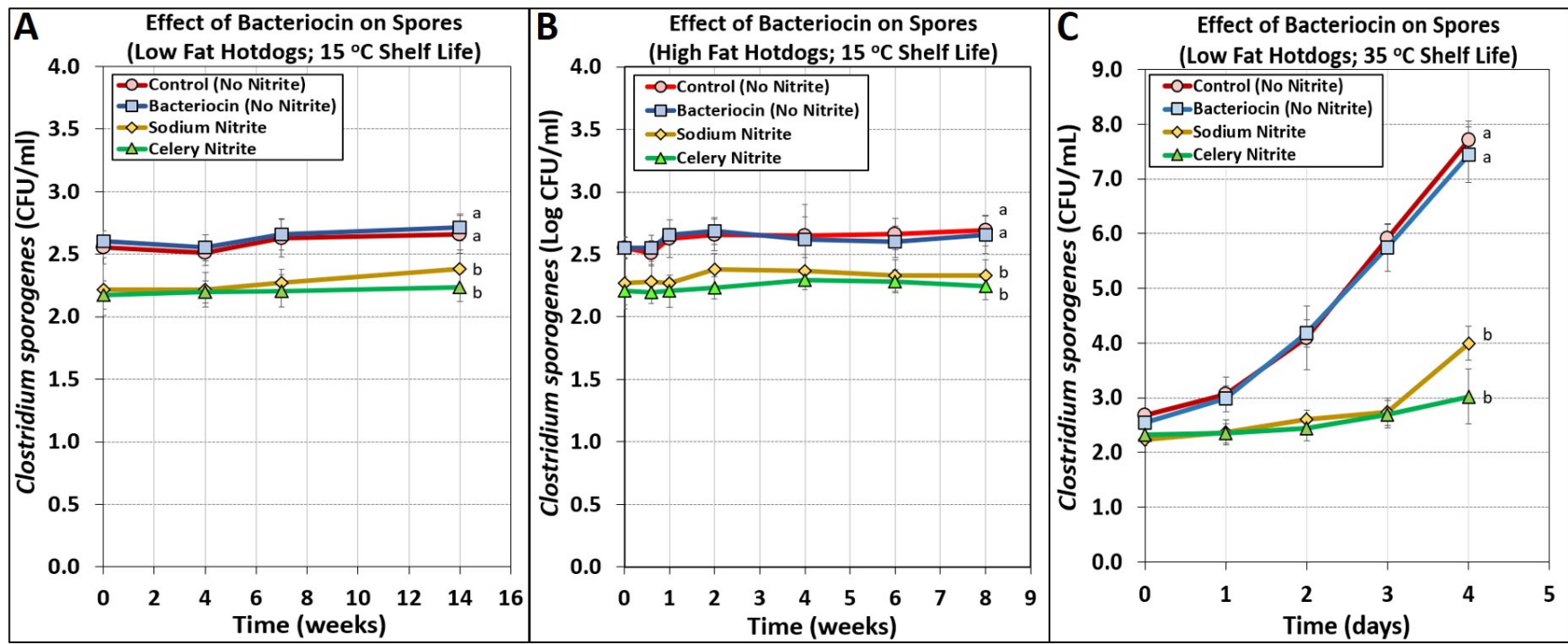

Figure 8. Enumeration of C. sporogenes from spore-inoculated low-fat (Panel A) and high-fat hotdogs (Panel B) manufactured without nitrite (control or bacteriocin), with sodium nitrite, or with celery nitrite held at $15{ }^{\circ} \mathrm{C}$. The same treatment with just low-fat hotdogs were also held at $35^{\circ} \mathrm{C}$ (Panel C) to determine if addition of bacteriocin preparations would be inhibitory to spore germination or vegetative cell growth. Treatments were the means of triplicate samples from each of two replications (total $n=6$ ). Time course treatments were analyzed by RM-ANOVA using the Holm-Sidak test for pairwise multiple comparisons to determine significant differences. Treatments with different letters are significantly different $(p<0.05)$. Treatments with the same letter are not significantly different $(p>0.05)$.

\section{Conclusions}

The data presented herein demonstrates that celery nitrite provides an equivalent level of control on germination and outgrowth of Clostridium sporogenes spores to sodium nitrite when used at equivalent levels in both low and high-fat hotdogs. Differences observed in spore counts from hotdogs without nitrite vs. those containing nitrite after cooking were attributed to some degree of lethality or inactivation of spores when cooked in the presence of nitrite. Our data suggest that proper refrigeration temperature alone is capable of preventing outgrowth of $C$. sporogenes even when no nitrite is present, and even at temperatures as high as $15^{\circ} \mathrm{C}$. Future studies might make better use of higher, permissive temperatures (i.e., $30-35{ }^{\circ} \mathrm{C}$ ) to show the effects of different product formulations and nitrite on clostridial spores. Food safety measures are often introduced for those occasional occurrences where physical control measures (i.e., temperature) have mechanical problems, and the use of nitrite provides a protective advantage to hotdogs (or other processed meats) in case such problems were to occur. In the US, the USDA-FSIS 'Appendix B' provides time-temperature parameters for post-process cooling (i.e., 'stabilization') of meat and poultry [61]. Currently, processors are concerned whether they should discard batches of product when failing to achieve required cooling in the designated time period that misses the allotted time by short periods. The current limitation for $C$. perfringens is that postprocessing cooling should not allow $>1-\log$ increase of $C$. perfringens in such products. It would be interesting to see if the nitrite spore control parameters identified in this study also apply to other Clostridium sp.

Author Contributions: Conceptualization, P.M.M.; methodology, P.M.M.; software, P.M.M.; validation, A.B., D.P.; formal analysis, A.B.; investigation, A.B., D.P., J.N.; resources, P.M.M., J.N.; data curation, P.M.M.; writing—original draft preparation, A.B.; writing—review and editing, P.M.M.; visualization, P.M.M.; supervision, P.M.M., J.N.; project administration, P.M.M.; funding acquisition, P.M.M. All authors have read and agreed to the published version of the manuscript.

Funding: This research was funded by a grant from the Beef Checkoff administered by the Foundation for Meat and Poultry Research and Education (G20001940), USDA-NIFA National Needs 
Fellowship (2016-11407), Advance Foods-SE Gilliland Professorship in Microbial Food Safety (2157200), USDA HATCH Project (OKL03090), Robert M. Kerr Food \& Ag Products Center (in kind support) and the Oklahoma Agricultural Experiment Station, DASNR (in kind support).

Institutional Review Board Statement: Not applicable.

Informed Consent Statement: Not applicable.

Data Availability Statement: Data available upon request.

Acknowledgments: The authors acknowledge the help of Kundan Shah with microbial plating and enumeration in some of the experiments in this study, and Florida Food Products LLP (Eustis, FL, USA) for providing the celery nitrite (VegSTable 504, 506) and the cherry extract (VegStable Cherry 515) used in this study.

Conflicts of Interest: The authors declare no conflict of interest.

\section{References}

1. Hatheway, C.L. Toxigenic clostridia. Clin. Microbiol. Rev. 1990, 3, 66-98. [CrossRef]

2. Al-Hinai, M.A.; Jones, S.W.; Papoutsakis, E.T. Sporulation programs: Diversity and preservation of endospore differentiation. Microbiol. Mol. Biol. Rev. 2015, 79, 19. [CrossRef]

3. Broussolle, V.; Alberto, F.; Shearman, C.A.; Mason, D.R.; Botella, L.; Nguyen-The, C.; Peck, M.W.; Carlin, F. Molecular and Physiological Characterisation of Spore Germination in Clostridium botulinum and C. sporogenes. Anaerobe 2002, 8, 89-100. [CrossRef]

4. Long, S.C.; Tauscher, T. Watershed issues associated with Clostridium botulinum: A literature review. J. Water Health 2006, 4, 277-288. [CrossRef]

5. García, S.; Heredia, N. Clostridium perfringens: A dynamic foodborne pathogen. Food Bioprocess Technol. 2011, 4, 624-630. [CrossRef]

6. Larsson, S.C.; Orsini, N.; Wolk, A. Processed meat consumption and stomach cancer risk: A meta-analysis. J. Natl. Cancer Inst. 2006, 98, 1078-1087. [CrossRef]

7. Bedale, W.; Sindelar, J.J.; Milkowski, A.L. Dietary nitrate and nitrite: Benefits, risks, and evolving perceptions. Meat Sci. 2016, 120, 85-92. [CrossRef]

8. Flores, M.; Toldrá, F. Chemistry, safety, and regulatory considerations in the use of nitrite and nitrate from natural origin in meat products-Invited review. Meat Sci. 2021, 171, 108272. [CrossRef] [PubMed]

9. Bhusal, A.; Muriana, P.M. Isolation and characterization of nitrate reducing bacteria for conversion of vegetable-derived nitrate to 'natural nitrite'. Appl. Microbiol. 2021, 1, 11-23. [CrossRef]

10. Hord, N.G.; Tang, Y.; Bryan, N.S. Food sources of nitrates and nitrites: The physiologic context for potential health benefits. Am. J. Clin. Nutr. 2009, 90, 1-10. [CrossRef] [PubMed]

11. Bahadoran, Z.; Mirmiran, P.; Jeddi, S.; Azizi, F.; Ghasemi, A.; Hadaegh, F. Nitrate and nitrite content of vegetables, fruits, grains, legumes, dairy products, meats and processed meats. J. Food Compos. Anal. 2016, 51, 93-105. [CrossRef]

12. Sullivan, G.A.; Jackson-Davis, A.L.; Niebuhr, S.E.; Xi, Y.; Schrader, K.D.; Sebranek, J.G.; Dickson, J.S. Inhibition of Listeria monocytogenes using natural antimicrobials in no-nitrate-or-nitrite-added ham. J. Food Prot. 2012, 75, 1071-1076. [CrossRef]

13. Jackson, A.L.; Kulchaiyawat, C.; Sullivan, G.A.; Sebranek, J.G.; Dickson, J.S. Use of natural ingredients to control growth of Clostridium perfringens in naturally cured frankfurters and hams. J. Food Prot. 2011, 74, 417-424. [CrossRef] [PubMed]

14. King, A.M.; Glass, K.A.; Milkowski, A.L.; Sindelar, J.J. Impact of clean-label antimicrobials and nitrite derived from natural sources on the outgrowth of Clostridium perfringens during cooling of deli-style turkey breast. J. Food Prot. 2015, 78, 946-953. [CrossRef] [PubMed]

15. Smith, C.J.; Olszewska, M.A.; Diez-Gonzalez, F. Selection and application of natural antimicrobials to control Clostridium perfringens in sous-vide chicken breasts: Inhibition of C. perfringens in sous-vide chicken. Int. J. Food Microbiol. 2021, $347,109193$. [CrossRef] [PubMed]

16. Johnson, E.M.; Jung, D.Y.-G.; Jin, D.Y.-Y.; Jayabalan, D.R.; Yang, D.S.H.; Suh, J.W. Bacteriocins as food preservatives: Challenges and emerging horizons. Crit. Rev. Food Sci. Nutr. 2018, 58, 2743-2767. [CrossRef]

17. Muriana, P.M. Bacteriocins for control of Listeria spp in food. J. Food Prot. 1996, 59, 54-63. [CrossRef]

18. Gálvez, A.; Abriouel, H.; López, R.L.; Ben Omar, N. Bacteriocin-based strategies for food biopreservation. Int. J. Food Microbiol. 2007, 120, 51-70. [CrossRef] [PubMed]

19. Gharsallaoui, A.; Joly, C.; Oulahal, N.; Degraeve, P. Nisin as a Food Preservative: Part 2: Antimicrobial polymer materials containing nisin. Crit. Rev. Food Sci. Nutr. 2016, 56, 1275-1289. [CrossRef]

20. Younes, M.; Aggett, P.; Aguilar, F.; Crebelli, R.; Dusemund, B.; Filipič, M.; Frutos, M.J.; Galtier, P.; Gundert-Remy, U.; Kuhnle, G.G.; et al. Safety of nisin (E 234) as a food additive in the light of new toxicological data and the proposed extension of use. EFSA J. 2017, 15, e05063. 
21. Burke, D.G.; Cotter, P.D.; Ross, R.P.; Hill, C. 14-Microbial production of bacteriocins for use in foods. In Microbial Production of Food Ingredients, Enzymes and Nutraceuticals; McNeil, B., Archer, D., Giavasis, I., Harvey, L., Eds.; Woodhead Publishing: Cambridge, UK, 2013; pp. 353-384.

22. Harlander, S.K. Chapter 11-Regulatory aspects of bacteriocin use. In Bacteriocins of Lactic Acid Bacteria; Hoover, D.G., Steenson, L.R., Eds.; Academic Press: Cambridge, MA, USA, 1993; pp. 233-247.

23. Diao, M.M.; André, S.; Membré, J.-M. Meta-analysis of D-values of proteolytic Clostridium botulinum and its surrogate strain Clostridium sporogenes PA 3679. Int. J. Food Microbiol. 2014, 174, 23-30. [CrossRef]

24. Brown, J.L.; Tran-Dinh, N.; Chapman, B. Clostridium sporogenes PA 3679 and its uses in the derivation of thermal processing schedules for low-acid shelf-stable foods and as a research model for proteolytic Clostridium botulinum. J. Food Prot. 2012, 75 , 779-792. [CrossRef]

25. Bradbury, M.; Greenfield, P.; Midgley, D.; Li, D.; Tran-Dinh, N.; Vriesekoop, F.; Brown, J.L. Draft genome sequence of Clostridium sporogenes PA 3679, the common nontoxigenic surrogate for proteolytic Clostridium botulinum. J. Bact. 2012, 194, 1631. [CrossRef]

26. Khanipour, E.; Flint, S.H.; Mccarthy, O.J.; Golding, M.; Palmer, J.; Ratkowsky, D.A.; Ross, T.; Tamplin, M. Modelling the combined effects of salt, sorbic acid and nisin on the probability of growth of Clostridium sporogenes in a controlled environment (nutrient broth). Food Control 2016, 62, 32-43. [CrossRef]

27. Taylor, R.H.; Dunn, M.L.; Ogden, L.V.; Jefferies, L.K.; Eggett, D.L.; Steele, F.M. Conditions associated with Clostridium sporogenes growth as a surrogate for Clostridium botulinum in nonthermally processed canned butter. J. Dairy Sci. 2013, 96, 2754-2764 [CrossRef] [PubMed]

28. Paredes-Sabja, D.; Gonzalez, M.; Sarker, M.R.; Torres, J.A. Combined effects of hydrostatic pressure, temperature, and pH on the inactivation of spores of Clostridium perfringens Type A and Clostridium sporogenes in buffer solutions. J. Food Sci. 2007, 72, M202-M206. [CrossRef] [PubMed]

29. Adhikari, A.; Yemmireddy, V.K.; Costello, M.J.; Gray, P.M.; Salvadalena, R.; Rasco, B.; Killinger, K. Effect of storage time and temperature on the viability of E. coli O157:H7, Salmonella spp., Listeria innocua, Staphylococcus aureus, and Clostridium sporogenes vegetative cells and spores in vacuum-packed canned pasteurized milk cheese. Int. J. Food Microbiol. 2018, 286, 148-154. [CrossRef]

30. Valero, A.; Olague, E.; Medina-Pradas, E.; Garrido-Fernández, A.; Romero-Gil, V.; Cantalejo, M.J.; García-Gimeno, R.M.; PérezRodríguez, F.; Posada-Izquierdo, G.D.; Arroyo-López, F.N. Influence of acid adaptation on the probability of germination of Clostridium sporogenes spores against $\mathrm{pH}, \mathrm{NaCl}$ and time. Foods 2020, 9, 127. [CrossRef]

31. Enfors, S.-O.; Molin, G. The influence of high concentrations of carbon dioxide on the germination of bacterial spores. J. Appl. Bacteriol. 1978, 45, 279-285. [CrossRef]

32. Garver, K.I.; Muriana, P.M. Detection, identification and characterization of bacteriocin-producing lactic acid bacteria from retail food products. Int. J. Food Microbiol. 1993, 20, 241-258. [CrossRef]

33. Henning, C.; Vijayakumar, P.; Adhikari, R.; Jagannathan, B.; Gautam, D.; Muriana, P.M. Isolation and taxonomic identity of bacteriocin-producing lactic acid bacteria from retail foods and animal sources. Microorganisms 2015, 3, 80-93. [CrossRef] [PubMed]

34. Henning, C.; Gautam, D.; Muriana, P. Identification of multiple bacteriocins in Enterococcus spp. using an Enterococcus-specific bacteriocin PCR array. Microorganisms 2015, 3, 1-16. [CrossRef]

35. Sandle, T. 14-Antibiotics and preservatives. In Pharmaceutical Microbiology; Sandle, T., Ed.; Woodhead Publishing: Oxford, UK, 2016; pp. 171-183.

36. Karolenko, C.E.; Bhusal, A.; Gautam, D.; Muriana, P.M. Selenite cystine agar for enumeration of inoculated Salmonella serovars recovered from stressful conditions during antimicrobial validation studies. Microorganisms 2020, 8, 338. [CrossRef] [PubMed]

37. Ocampo, P.S.; Lázár, V.; Papp, B.; Arnoldini, M.; Abel Zur Wiesch, P.; Busa-Fekete, R.; Fekete, G.; Pál, C.; Ackermann, M.; Bonhoeffer, S. Antagonism between bacteriostatic and bactericidal antibiotics is prevalent. Antimicrob. Agents Chemother. 2014, 58, 4573-4582. [CrossRef] [PubMed]

38. Singh, N.; Yeh, P.J. Suppressive drug combinations and their potential to combat antibiotic resistance. J. Antibiot. 2017, 70, 1033-1042. [CrossRef] [PubMed]

39. Perkins, W.E. Production of clostridial spores. J. Appl. Bacteriol. 1965, 28, 1-16.

40. Yang, W.W.; Crow-Willard, E.N.; Ponce, A. Production and characterization of pure Clostridium spore suspensions. J. Appl. Microbiol. 2009, 106, 27-33. [CrossRef] [PubMed]

41. Bozzola, J.J. Conventional specimen preparation techniques for scanning electron microscopy of biological specimens. In Electron Microscopy: Methods and Protocols; Kuo, J., Ed.; Humana Press: Totowa, NJ, USA, 2007; pp. 449-466.

42. Bray, D.F.; Bagu, J.; Koegler, P. Comparison of hexamethyldisilazane (HMDS), Peldri II, and critical-point drying methods for scanning electron microscopy of biological specimens. Microsc. Res. Tech. 1993, 26, 489-495. [CrossRef]

43. Pettinati, J.D.; Swift, C.E. Rapid determination of fat in meat and meat products by Foss-let solvent extraction and density measurement. J. Assoc. Off. Anal. Chem. 2020, 58, 1182-1187. [CrossRef]

44. Su, Y.K.; Bowers, J.A.; Zayas, J.F. Physical characteristics and microstructure of reduced-fat frankfurters as affected by salt and emulsified fats stabilized with nonmeat proteins. J. Food Sci. 2000, 65, 123-128. [CrossRef]

45. Vijayakumar, P.; Muriana, P. Inhibition of Listeria monocytogenes on ready-to-eat meats using bacteriocin mixtures based on mode-of-action. Foods 2017, 6, 22. [CrossRef] 
46. Macwana, S.; Muriana, P.M. Spontaneous bacteriocin resistance in Listeria monocytogenes as a susceptibility screen for identifying different mechanisms of resistance and modes of action by bacteriocins of lactic acid bacteria. J. Microbiol. Methods 2012, 88, 7-13. [CrossRef] [PubMed]

47. National Advisory Committee on the Microbiological Criteria for Foods. Parameters for determining inoculated pack/challenge study protocols. J. Food Prot. 2010, 73, 140-202. [CrossRef] [PubMed]

48. USDA-FSIS. FSIS Compliance Guideline HACCP Systems Validation; USDA-FSIA: Washington, DC, USA, $2015 ;$ pp. 1-68.

49. Janganan, T.K.; Mullin, N.; Tzokov, S.B.; Stringer, S.; Fagan, R.P.; Hobbs, J.K.; Moir, A.; Bullough, P.A. Characterization of the spore surface and exosporium proteins of Clostridium sporogenes; implications for Clostridium botulinum group I strains. Food Microbiol. 2016, 59, 205-212. [CrossRef]

50. Calderón-Romero, P.; Castro-Córdova, P.; Reyes-Ramírez, R.; Milano-Céspedes, M.; Guerrero-Araya, E.; Pizarro-Guajardo, M.; Olguín-Araneda, V.; Gil, F.; Paredes-Sabja, D. Clostridium difficile exosporium cysteine-rich proteins are essential for the morphogenesis of the exosporium layer, spore resistance, and affect C. difficile pathogenesis. PLoS Pathog. 2018, 14, e1007199. [CrossRef]

51. Gøtterup, J.; Olsen, K.; Knöchel, S.; Tjener, K.; Stahnke, L.H.; Møller, J.K. Relationship between nitrate/nitrite reductase activities in meat associated staphylococci and nitrosylmyoglobin formation in a cured meat model system. Int. J. Food Microbiol. 2007, 120, 303-310. [CrossRef]

52. Gøtterup, J.; Olsen, K.; Knøchel, S.; Tjener, K.; Stahnke, L.H.; Møller, J.K. Colour formation in fermented sausages by meatassociated staphylococci with different nitrite- and nitrate-reductase activities. Meat Sci. 2008, 78, 492-501. [CrossRef]

53. Vareltzis, K.; Buck, E.M.; Labbe, R.G. Effectiveness of a betalains/potassium sorbate system versus sodium nitrite for color development and control of total aerobes, Clostridium perfringens and Clostridium sporogenes in chicken frankfurters. J. Food Prot. 1984, 47, 532-536. [CrossRef] [PubMed]

54. Jackson, A.L.; Sullivan, G.A.; Kulchaiyawat, C.; Sebranek, J.G.; Dickson, J.S. Survival and growth of Clostridium perfringens in commercial no-nitrate-or-nitrite-added (natural and organic) frankfurters, hams, and bacon. J. Food Prot. 2011, 74, 410-416. [CrossRef]

55. Hong, Y.-K.; Huang, L.; Yoon, W.B. Mathematical modeling and growth kinetics of Clostridium sporogenes in cooked beef. Food Control 2016, 60, 471-477. [CrossRef]

56. Rayman, M.K.; Aris, B.; Hurst, A. Nisin: A possible alternative or adjunct to nitrite in the preservation of meats. Appl. Environ. Microbiol. 1981, 41, 375. [CrossRef]

57. Taylor, S.L.; Somers, E.B.; Krueger, L.A. Antibotulinal effectiveness of nisin-nitrite combinations in culture medium and chicken frankfurter emulsions. J. Food Prot. 1985, 48, 234-239. [CrossRef] [PubMed]

58. Mazzotta, A.S.; Crandall, A.D.; Montville, T.J. Nisin resistance in Clostridium botulinum spores and vegetative cells. Appl. Environ. Microbiol. 1997, 63, 2654-2659. [CrossRef] [PubMed]

59. Hurst, A. Nisin. In Advances Applied Microbiology; Perlman, D., Laskin, A.I., Eds.; Academic Press: Cambridge, MA, USA, 1981; Volume 27, pp. 85-123.

60. Han, S.-K.; Shin, M.-S.; Park, H.-E.; Kim, S.-Y.; Lee, W.-K. Screening of bacteriocin-producing Enterococcus faecalis strains for antagonistic activities against Clostridium perfringens. Korean J. Food Sci. Anim. Resour. 2014, 34, 614-621. [CrossRef] [PubMed]

61. USDA-FSIS. Verification Procedures for Lethality and Stabilization; USDA-FSIS: Washington, DC, USA, 2017; Volume 7111.1, pp. 1-21. 